\title{
Microbiology and atmospheric processes: the role of biological particles in cloud physics
}

\author{
O. Möhler ${ }^{1}$, P. J. DeMott ${ }^{2}$, G. Vali ${ }^{3}$, and Z. Levin ${ }^{4}$ \\ ${ }^{1}$ Institute for Meteorology and Climate Research (IMK-AAF), Forschungszentrum Karlsruhe, Germany \\ ${ }^{2}$ Department of Atmospheric Science, Colorado State University, Fort Collins, CO, USA \\ ${ }^{3}$ Department of Atmospheric Science, University of Wyoming, Laramie, WY, USA \\ ${ }^{4}$ Department of Geophysics and Planetary Science, The Raymond and Beverly Sackler Faculty of Exact Sciences, Tel Aviv \\ University, Israel
}

Received: 17 July 2007 - Published in Biogeosciences Discuss.: 2 August 2007

Revised: 19 November 2007 - Accepted: 20 November 2007 - Published: 3 December 2007

\begin{abstract}
As part of a series of papers on the sources, distribution and potential impact of biological particles in the atmosphere, this paper introduces and summarizes the potential role of biological particles in atmospheric clouds. Biological particles like bacteria or pollen may be active as both cloud condensation nuclei (CCN) and heterogeneous ice nuclei (IN) and thereby can contribute to the initial cloud formation stages and the development of precipitation through giant $\mathrm{CCN}$ and IN processes. The paper gives an introduction to aerosol-cloud processes involving $\mathrm{CCN}$ and IN in general and provides a short summary of previous laboratory, field and modelling work which investigated the $\mathrm{CCN}$ and IN activity of bacterial cells and pollen. Recent measurements of atmospheric ice nuclei with a continuous flow diffusion chamber (CFDC) and of the heterogeneous ice nucleation efficiency of bacterial cells are also briefly discussed. As a main result of this overview paper we conclude that a proper assessment of the impact of biological particles on tropospheric clouds needs new laboratory, field and modelling work on the abundance of biological particles in the atmosphere and their $\mathrm{CCN}$ and heterogeneous IN properties.
\end{abstract}

\section{Introduction}

Atmospheric aerosols influence cloud formation and precipitation development, and thus have important impacts on the global climate, the water cycle, and atmospheric chemical reactions (Solomon et al., 2007). Much research has been done in this regard for particle types previously thought to represent the majority (by number) of aerosols in the atmosphere, for example, sulphates and organic particles formed

Correspondence to: O. Möhler

(ottmar.moehler@imk.fzk.de) by nucleation processes, windblown sea salt and mineral dusts, primary pollutants and smoke particles from natural and manmade forest fires. Less is known about what specific contribution is made by primary biological aerosol particles (those directly emitted into the atmosphere) to cloud formation through their effects on cloud droplet and ice crystal initiation. Their potentially high numbers in the lower levels of the atmosphere (Jaenicke, 2005), wide distribution over vegetative surfaces and oceans, and likely strong seasonal and climatic variability compared to other organic or inorganic particles in the atmosphere make it important to focus on this group collectively. Also, indications that biogenic particles possess specific cloud-activation properties, such as preference for nucleation of liquid droplets and ice crystals, make them important for more focused future studies.

Biological particles may, like aerosol particles of other origin (e.g. mineral dust, sea salt, biomass smoke, pollution particles, particles nucleated from gas phase emissions of many types), influence cloud formation and precipitation processes via the following paths: (i) the phase change from vapour to liquid, (ii) the acceleration of coalescence by large particles; and (iii) the phase change from vapour or liquid to ice. Details of these processes are described in several textbooks (e.g., Pruppacher and Klett, 1997; Rogers and Yau, 1989; Young, 1993). In path (ii), only the size, shape, and density of the particles are important. The other two processes depend on more specific properties, as will be discussed. It may be pointed out that from what is known at this time, ice nucleation by biological aerosol particles is expected to have the greatest potential for influencing cloud evolution.

It is the purpose of this article to examine what is known about the characteristics of primary biological aerosol particles like cells (e.g., bacteria, spores, fungi, viruses, algae, pollen) or cellular material/fragments and proteins injected

Published by Copernicus Publications on behalf of the European Geosciences Union. 


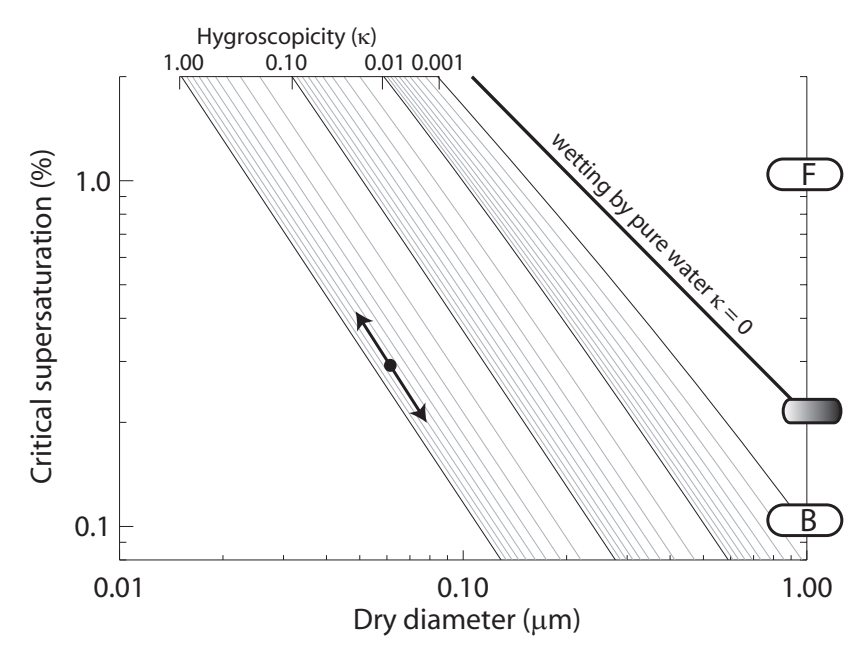

Fig. 1. The critical supersaturation (RH-100\%) for cloud droplet activation of a hygroscopic and soluble inorganic particle (filled circles) as a function of its size (arrows show the relation for a particular particle composition/hygroscopicity) compared to a "wettable" bacterium of 1 micron size (filled, rounded rectangle). Actual measurements of CCN critical supersaturations of different bacteria, from (F) (Franc and DeMott, 1998) and (B) (Bauer et al., 2003) are shown (see text). The figure and hygroscopicity scale $(\kappa=0$ occurs at the Kelvin diameter) are adapted from Petters and Kreidenweis (2007).

directly as particles from the biosphere (Mathias-Maser, 1998), and to summarize the potential impact of these particles on atmospheric clouds. It should be noted that we restrict this discussion to primary biological particles. Other recent literature is available concerning the possible effects of secondary particles produced from processing of gas phase emissions from biogenic sources, on clouds and atmospheric radiative transfer (Barth et al., 2005; Cziczo et al., 2004; Facchini et al., 1999; Kanakidou et al., 2005; Maria et al., 2004; Shilling et al., 2006; Sun and Ariya, 2006).

Processes of CCN activation and initiation of precipitation in warm clouds, i.e. clouds only composed of liquid droplets without the ice phase present, will be discussed in Sects. 2 and 3. Ice processes in mixed-phase clouds involving both liquid and ice-phase processes and a classification of ice nucleation processes are subjects of Sects. 4 and 5, respectively. Although biological particles may impact even high cirrus clouds, cirrus cloud processes are not treated in this paper. Section 6 summarizes measurements of atmospheric ice nuclei. Sections 7 and 8 give an introduction to the discovery of ice nucleation active (INA) bacteria and to laboratory measurements of the ice nucleation activity of biological particles. Section 9 describes some first cloud modelling work on the impact of biogenic ice nuclei on clouds and precipitation.

\section{Aerosol particles as cloud condensation nuclei $(\mathrm{CCN})$}

Clouds form through the condensation of water vapour onto aerosol particles when the relative humidity ( $\mathrm{RH}$ in \%) exceeds saturation with respect to the pertinent phase (water or ice) over the particle surface. This is a kinetic process that is controlled by the size, composition and surface properties of the particles. Particles that serve as nuclei for liquid cloud formation at a specified RH are referred to as cloud condensation nuclei $(\mathrm{CCN})$, while those that serve as nuclei for ice formation are called ice nuclei (IN). We discuss these nuclei and their cloud impacts separately below.

In a classical sense, $\mathrm{CCN}$ activation to form cloud droplets occurs most readily on particles that require the lowest supersaturation (RH-100\%). This supersaturation is determined by the size and soluble mass content of particles through Köhler theory (Köhler, 1936), which describes the combined effects of the elevation of RH by the curved surface of particles (Kelvin effect) and lowering of RH by dissolved solute (Raoult effect). This theoretical treatment is valid for watersoluble inorganic and organic particles, and modifications to this theory are capable of describing such complexities as partial solubility, surface effects or other non-idealities. The uptake of water by bacteria and other biological particles is not well understood and so classical descriptions of $\mathrm{CCN}$ activation may not be valid or readily extended. Water uptake below $100 \%$ RH, clearly indicated in some bacterial studies (Ko et al., 2000; Peccia et al., 2001), may involve absorbed water due to the presence of solutes, or other physically or chemically facilitated adsorption processes. Non-soluble biological particles that are "wettable" on their surface will behave as $\mathrm{CCN}$ at their Kelvin diameter (Fig. 1). This necessarily occurs at a higher supersaturation than that at which most other atmospheric CCN activate droplet formation, but a large enough particle may activate as a CCN at a similar supersaturation as a small soluble particle (Fig. 1).

Which particles, in a diverse population including biological particles, act as $\mathrm{CCN}$ for real liquid cloud formation depends both on the number concentrations of the different $\mathrm{CCN}$ types (characterized by their critical activation $R H$ ) and on the dynamics of cloud formation. Vertical air motions (updrafts), or the mixing of air masses with different temperatures and moisture contents, can lead to the supersaturations necessary for cloud formation. Once droplets have activated, their continued growth occurs by the deposition of water vapour for as long as water supersaturation is maintained by persisting vertical motion. This uptake of vapour by droplets limits further increase of supersaturation and prevents $\mathrm{CCN}$ activation of further additional particles. Consequently, CCN that activate at the lowest RH above $100 \%$ are the most important ones for cloud formation, including a range of sizes of soluble particles and larger wettable particles that likely include bacteria and pollen.

The activation of aerosol particles as $\mathrm{CCN}$ can be determined by so-called cloud condensation nucleus counters 
(Delene et al., 1998; Roberts and Nenes, 2005). These devices yield a measurement of the number concentration of particles that form droplets in a volume of air at predetermined supersaturations. Those measurements, combined with calculations of the vapour versus liquid balance in cloud models, yield a reasonably adequate description of initial cloud formation. Alternatively, the activation process can be predicted from the size distribution and assumed composition of the aerosol entering a cloud.

Only a few measurements of CCN activation of primary biological aerosol particles, PBAP, exist and these are for bacteria. Franc and DeMott (1998) found different fractions of various strains of plant pathogenic Erwinia carotovora bacteria to activate over a wide range of supersaturations. Their data point plotted in Fig. 1 shows that $30 \%$ of these bacteria activate as $\mathrm{CCN}$ only for critical supersaturations exceeding those indicating wettability. Bauer et al. (2003) on the other hand found that nearly $100 \%$ of four bacterial isolates from atmospheric samples activated as $\mathrm{CCN}$ at supersaturations around $0.1 \%$, or better than for wettable particles of the same volume equivalent diameters. Levin et al. (1987) tested the growth of freeze/dried bacteria in saturated environment and showed a rapid growth by absorption of water vapor. These data suggest that a substantial proportion of bacteria in the atmosphere are likely to activate as wettable or in a manner like more hygroscopic particles at their sizes and so are probably frequently scavenged into drops by nucleation during cloud formation. $\mathrm{CCN}$ activation of pollen particles might be inferred based on indications of water uptake by these particles at relative humidity below 100\% (Diehl et al., 2001). From the standpoint of contributions to the total number concentrations of particles activated in clouds, it seems likely that bacteria and pollen usually have a minor impact. But larger $\mathrm{CCN}$ also possess special capabilities, for the reasons mentioned next.

\section{Rain initiation in warm clouds}

Interestingly, cloud droplets cannot grow to precipitation sizes by vapour deposition alone in the time intervals commonly available in clouds. Evolution of precipitation in clouds not containing ice is greatly accelerated by coalescence, whereby cloud drops collide and merge to create larger droplets. The initial growth in diameter by vapour deposition after CCN activation is inversely related to the particle diameter (e.g., Pruppacher and Klett, 1997). Thus, activated droplets having smaller diameters initially grow faster in size than larger ones, leading to a narrowing of the droplet size distributions as shown in Fig. 2.

Precipitation drops have sizes ranging from about $0.1 \mathrm{~mm}$ to a few $\mathrm{mm}$. Since coalescence depends on differences in fall velocity, the coalescence process can be greatly facilitated by the presence of larger (up to approximately $2 \mu \mathrm{m}$ ) or "giant" $(>2 \mu \mathrm{m}) \mathrm{CCN}$, termed GCCN, that tend to gener-

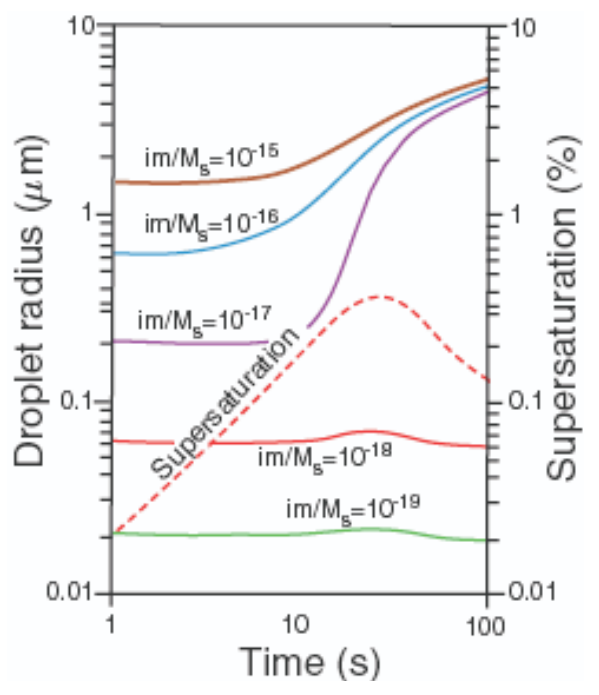

Fig. 2. Theoretical computations of the growth of cloud condensation nuclei by condensation in a parcel of air rising with a speed of $60 \mathrm{~cm} \mathrm{~s}^{-1}$. A total CCN number concentration of $500 \mathrm{~cm}^{-3}$ was assumed with $\mathrm{im} / M_{S}$ values as indicated; $m$ is the mass of material dissolved in the droplet, $M_{S}$ the molecular weight of the material, and $i$ its van't Hoff factor (i.e., the number of ions produced by each molecule of the material when it dissolves). Thus, $i m / M_{S}$ is the effective number of kilomoles of the material in the dissolved droplet. One can think of the terms im as representing the particular chemical properties of the salt. Note how the droplets that have been activated (brown, blue and purple curves) approach a monodispersed size distribution after just 100 s (i.e. $\approx 60 \mathrm{~m}$ above cloud base). The variation with time of the supersaturation of the air parcel is also shown (dashed red line), taken from Wallace and Hobbs (2006), based on data from Howell (1949).

ate larger drops with faster fall velocity. GCCN may include sea salt, mineral dust, and biological particles. Among biological particles, pollen is the largest and most likely participant as a GCCN. GCCN, even in concentrations as small as $10^{-3} \mathrm{~cm}^{-3}$, are more effective in altering the timing, intensity and amount of precipitation in clouds with higher droplet concentrations (e.g. polluted clouds) than in clean clouds (Costa and Sherwood, 2005; Feingold et al., 2005; Teller and Levin, 2006; Yin et al., 2000).

In summary, as regards primary biological particle impacts on warm cloud processes, the key factors are wettability and water uptake, ability to act as $\mathrm{CCN}$, number concentrations and spatial distribution in the atmosphere, and physical size. If bacteria and pollen are wettable and therefore start to condense water at very low supersaturations, they fall in the range of large and giant $\mathrm{CCN}$, respectively (see Fig. 3), and therefore have a potential role in the initiation of precipitation in warm clouds, depending of course on their relative numbers compared to other aerosols of similar characteristics. 


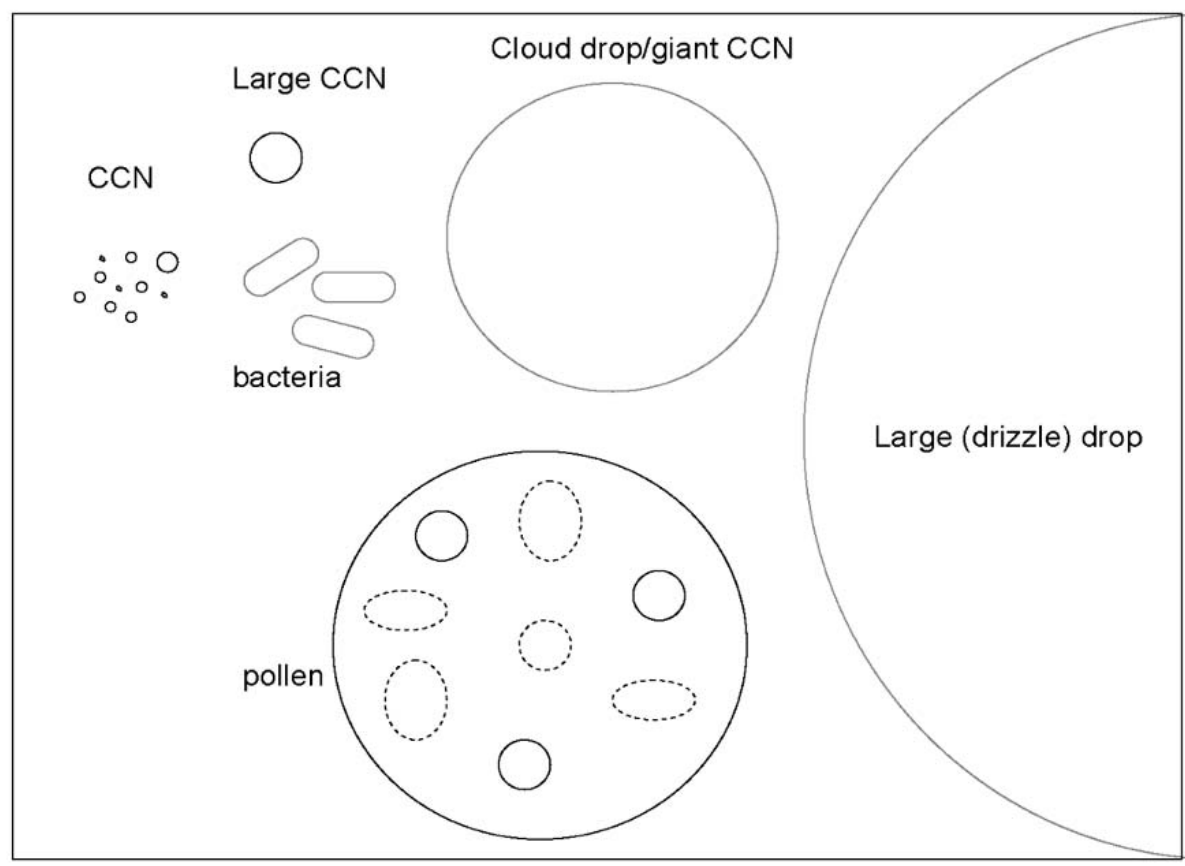

Fig. 3. Representation of warm cloud processes in which biological particles may be involved.

\section{Ice formation in clouds}

The presence of ice particles in clouds is a major factor in the formation of precipitation, the radiative properties of clouds, and the chemical interactions within clouds. It is also clearly established that a substantial fraction of clouds in the troposphere is composed totally or partially of ice particles. A major part of global precipitation, whether it arrives at the Earth's surface as rain or as some form of ice, has gone through some ice process. The principal reasons for this are that clouds easily extend to the colder temperatures of the atmosphere, and in a situation where both liquid and solid cloud particles exist the latter are favoured to grow to precipitation sizes.

While the importance of the ice phase in clouds is clear, major uncertainties still exist about the factors controlling the origins and abundance of ice particles in clouds. Observations show that number concentrations of ice particles are much lower and vary over a much larger range than those of cloud droplets (Rogers and Yau, 1989; Pruppacher and Klett, 1997). From the lowest measurement limit of perhaps $1 \mathrm{~m}^{-3}$, ice concentrations can reach up to $10^{6} \mathrm{~m}^{-3}$ or more. In comparison, liquid droplet concentrations range from about $10^{7}$ to $10^{11} \mathrm{~m}^{-3}$. The question of ice nucleation in clouds is further complicated by the fact that there are no general theories - in a comparable way to the roles of solubility and size for $\mathrm{CCN}$ activity - to indicate what characteristics determine ice nucleating activity. Some factors are known to be relevant and will be mentioned later.
A rather significant consequence of the relatively low number concentration of ice nuclei in the atmosphere is that ice does not appear in clouds with the same sharp threshold as is observed for condensation. Essentially all cloud droplets form within a few tens of meters at the base of a cumulus cloud. In contrast, ice particles originate in a more distributed fashion and most clouds are supercooled for some portion of their evolution, leading to "mixed-phase clouds" in which supercooled droplets are intermingled with some ice particles. Under such conditions, the lower vapour pressure of ice favours a transfer of water mass from the droplets to the ice particles, with the consequent growth of ice, and diminution of cloud water mass. This is known as the WegenerBergeron-Findeisen process. Once the ice particles acquire enough mass to fall at appreciable velocities, they also collect droplets by collisions that freeze on impact, a process called riming. These are the basic elements of precipitation formation in the vast majority of clouds, albeit they are not the whole story; the growth of various ice crystal shapes, the intricacies of the riming process leading to graupel and possibly to hailstones, the aggregation of crystals into snowflakes, and so on, will not be discussed here.

It will be shown, when discussing laboratory results for various populations of ice nucleating substances, that the propensity to initiate the phase transition increases with lowering temperatures. This is also a general feature of theoretical predictions. The manifestation of this trend in clouds is that often the concentration (number per volume of air) of ice particles increases with decreasing temperatures. In such 
cases, the ice particles that start at the highest temperatures below $0^{\circ} \mathrm{C}$ have the longest possible growth times and the greatest chance to develop to precipitation sizes. This is one of the reasons for the special interest in biogenic ice nuclei, since, as will be shown, they are known to be capable of nucleating ice at those high temperatures.

However, the situation is more complex. It has not been possible up to this time to demonstrate a clear agreement between measurements of ice nucleus number concentrations as a function of temperature and ice crystal number concentrations in clouds. Reasons for this are many. Most importantly, both types of measurements are exceedingly difficult to make. Secondly, ice crystals can be produced from secondary processes resulting from interactions among ice particles (fragmentation) or with water droplets (splinter ejection from freezing droplets). By contrast, ice nucleation is termed the primary process of ice generation. As a result, the expectation of monotonic increase in ice number concentrations with decreasing temperatures that would result from ice nucleation is of limited validity, and the limits are not well known. The overall result is that the prediction of ice number concentrations in clouds, from either direct ice nucleus measurements or from other characteristics of the aerosol, is currently possible to rather limited extents. This situation is further clarified in the following.

Analyses of ice number concentrations in a large number of stratiform and frontal clouds showed no relation between temperature and the concentrations of ice crystals down to sizes of $125 \mu \mathrm{m}$ (e.g., Field et al., 2005; Gultepe et al., 2001; Korolev et al., 2003). Many of these observations cannot be explained by known secondary ice formation processes. The discrepancy between these observations and the expectations based on ice formation by ice nuclei may be partly due to ice crystal redistribution in the clouds, but may also indicate the possibility that primary and/or secondary ice formation mechanisms not yet identified are responsible. Some investigators suggest that evaporation of cloud droplets is associated with the formation of ice (Cooper, 1995; Cotton and Field, 2002; Hobbs and Rangno, 1985). No mechanism for this has been identified so far, and present techniques of measuring ice nucleation by aerosols do not detect this process.

\section{Ice nucleation}

Ice can form in the atmosphere either from the vapor or from the liquid phases of water - these are distinguished as "deposition" and "freezing" (Vali, 1985a). The ice nucleation pathway of interest here is initiated on the surface of some particles, a process called heterogeneous nucleation. At temperatures approaching $-40^{\circ} \mathrm{C}$, supercooled liquid will freeze spontaneously, by homogeneous freezing nucleation. This latter process is well studied. It is time-dependent, with the rate rising extremely rapidly near $-35^{\circ} \mathrm{C}$, depends on the amount of dissolved substances in the water, and for a population of droplets means that freezing is most likely in the larger droplets. The latter arises from the fact that the probability of homogeneous freezing per unit volume and per unit time is the fundamental quantity governing the process. This was demonstrated in recent work for water droplets larger than a few microns in diameter (Duft and Leisner, 2004; Benz et al., 2005). It has been suggested that homogeneous freezing may occur preferentially close to the surface-air interface of drops (Tabazadeh et al., 2002). At least for droplets smaller than a few microns in diameter existing data are not of sufficient quantitative accuracy to differentiate whether surface or volumetric nucleation rates dominate (Koop, 2004).

Heterogeneous ice nucleation can take on further variations in clouds, beyond the basic ones of deposition and freezing. Laboratory results showed that the prior history of how a particle gets into the liquid makes a difference; this led to identifying three modes of freezing nucleation: immersion-, condensation- and contact-freezing (Vali, 1985a; Pruppacher and Klett, 1997). Furthermore, nucleation activity has been found to be influenced in some cases by pre-activation or prior exposure to low temperatures and/or humidity conditions, by memory (hysteresis) effects, UV radiation, and electric fields among other things (e.g., Roberts and Hallett, 1968; Schaller and Fukuta, 1979; Pruppacher and Klett, 1997). On the other hand, repeated cycles of freezing and melting in the laboratory lead to the conclusion that most ice nucleation is due to robust features that cause freezing at close to the same temperature over and over (Anderson and Hallett, 1976).

Theoretical treatments lead to estimates of the sizes of the surface sites responsible for nucleation (Pruppacher and Klett, 1997). That size decreases with temperature, from the order of $0.01 \mu \mathrm{m}$ for freezing a few degrees below $0^{\circ} \mathrm{C}$ to a tenth of that for temperatures near $-20^{\circ} \mathrm{C}$. However, there is no empirical confirmation for these figures. Beyond size, both theory and observations indicate that the nucleating sites are likely to possess crystallographic arrangements of molecules similar to that of water. Silver iodide is one of the substances that bear out this fact. It is also believed that steps, cavities and other surface features of crystalline materials might enhance their potential for ice nucleation. Hydrogen bonding to the ice lattice is likely to be a factor for organic substances.

\section{Measurements of atmospheric ice nuclei}

During the past decades, the knowledge about the nature and number concentration of atmospheric ice nuclei has significantly been improved by the application of new instruments and experimental methods in field measurements and laboratory studies. There are two different ways to study the nature of ice nuclei in the atmosphere. The first is to look at particles at the centres of snow crystals or in their residues 
(e.g., Heintzenberg et al., 1996; Targino et al., 2006). A variation of this is to collect small ice crystals following nucleation in a laboratory cloud chamber or field instrument and then analysing the residual particles by electron microscopy (Chen et al., 1998) or single particle mass spectrometry (Cziczo et al., 2003; Richardson et al., 2007). Second, relationships can be sought between aerosol composition, as determined by any of the variety of techniques available, and the abundance of ice in clouds that form in the sampled air mass.

For the first approach of direct analysis of residual particles from evaporating ice crystals care has to be taken that after the nucleation event the sampled ice crystals grew mainly by vapour diffusion and did not collect further aerosol particles e.g. by scavenging or riming processes. It should be noted that even if pristine, freshly nucleated ice crystals are sampled to avoid the effect of secondary particle collection, there is still the chance that non-detectable trace mixtures of other materials on a larger carrier particle may be responsible for ice nucleation. The correlation approach is affected by the fact that ice nuclei constitute a very small fraction of the total aerosol population in the atmosphere, so that a significant parallel between the aerosol composition and ice nucleation can be established only if there is a dominant and well identifiable source of aerosol that contributes to the observed ice formation.

Field measurements of atmospheric ice nuclei have been made with a variety of different instruments (e.g., Gagin and Aroyo, 1969; Huffman, 1973; Rogers, 1982; Al-Naimi and Saunders, 1985; Stein and Georgii, 1985; Vali, 1985b; Bigg, 1990; Rogers et al., 2001; Richardson et al., 2007). These measurements yield ice nuclei spectra: number concentration as a function of temperature and/or some measure of supersaturation (with respect to water or ice). Fundamentally, all of these instruments attempt to mimic cloud processes by creating equivalent conditions within a chamber filled with outside air (Rogers, 1993). The degree of realism of these simulations varies greatly and may be limited to one, or a few of the possible modes of ice nucleation activity. At temperatures above $-10^{\circ} \mathrm{C}$, the low number concentration of atmospheric ice nuclei makes it practically impossible to produce meaningful measurements in instruments of sizes that can be deployed in the field. Figure 4 indicates that the concentrations of ice nuclei in the free troposphere fall sharply at these warmer temperatures, while increasing only modestly at below $-25^{\circ} \mathrm{C}$ depending on locale, season and other possible factors. High frequency measurements are difficult under any circumstances, since sampling rates can be as low as $11 \mathrm{~min}^{-1}$.

Both inorganic and organic particles have been identified as atmospherically relevant ice nuclei. Mineral dusts are a general category of inorganic particles that are a reported and sometimes strong source of ice nuclei to the atmosphere (DeMott et al., 2003b; Isono et al., 1959). Biological particles, including certain bacteria, pollen, and decayed organic material have also been identified as ice nuclei (e.g. reviews by
Cantrell and Heymsfield, 2005; Morris et al., 2004; Szyrmer and Zawadzki, 1997). Section 7 presents a discussion of these.

The difficulty of demonstrating directly that ice nuclei predict ice formation in clouds has already been mentioned. It requires measurement of ice nuclei number concentration dependence on temperature and supersaturation for nuclei with a clearly defined pathway into and through a cloud for which both thermodynamic conditions and ice number concentrations are accurately documented and secondary ice formation processes are not expected to occur. Obtaining this information nearly simultaneously is difficult. Further, cloud supersaturation cannot presently be measured (it can only be inferred from numerical calculations based on cloud droplet size distribution and cloud updraft measurements), existing cloud particle measuring instruments do not resolve cloud phase (ice versus water), making identification of freshly nucleated (small) ice crystals very difficult, and high resolution ice nuclei measuring systems for aircraft are a relatively recent development. Consequently, at present, there exists mainly indirect evidence that ice nuclei predict ice formation in clouds. This evidence comes from observing the onset of ice formation in clouds with simple motions and cloud regions where the action of primary ice nucleation processes is expected to be isolated (e.g., Cooper and Vali, 1981; Cooper, 1986; Rasmussen et al., 2002). These studies note the general increase of initial ice number concentrations with decreasing cloud temperature, consistent with expectations and recent measurements of the number concentrations and behaviour of ice nuclei present in air at cloud altitudes (e.g., DeMott et al., 2003a; Prenni et al., 2007). In the only reported direct comparison of ice crystal concentrations and ice nuclei concentrations measured with a real-time airborne instrument, Rogers and DeMott (2002) found good correspondence in a series of orographic wave clouds.

\section{Ice nuclei of biological origin}

Drop-freezing tests with soil samples (Vali, 1968) showed that ice nucleation activity was significantly higher when the organic content of the soil was high. Rich top soils and peat, for example, were found to contain ice nuclei active at temperatures as high as $-4^{\circ} \mathrm{C}$. The relationship between organic content and ice nucleating ability also extends to differences with climate region, as shown by Schnell and Vali (1976). The source of ice nuclei in soils was narrowed to decaying vegetation (Schnell and Vali, 1972) and was further narrowed to bacteria (Pseudomonas syringae) participating in the decay process (Maki et al., 1974; Vali et al., 1976). Remarkably, with each step of isolation of the active agent, ice nucleating activity shifted to higher temperatures; bacterial cultures contain ice nuclei active at temperatures as high as $-2^{\circ} \mathrm{C}$. That is several degrees warmer than other ice nuclei; silver iodide, one of the most active inorganic substances, 


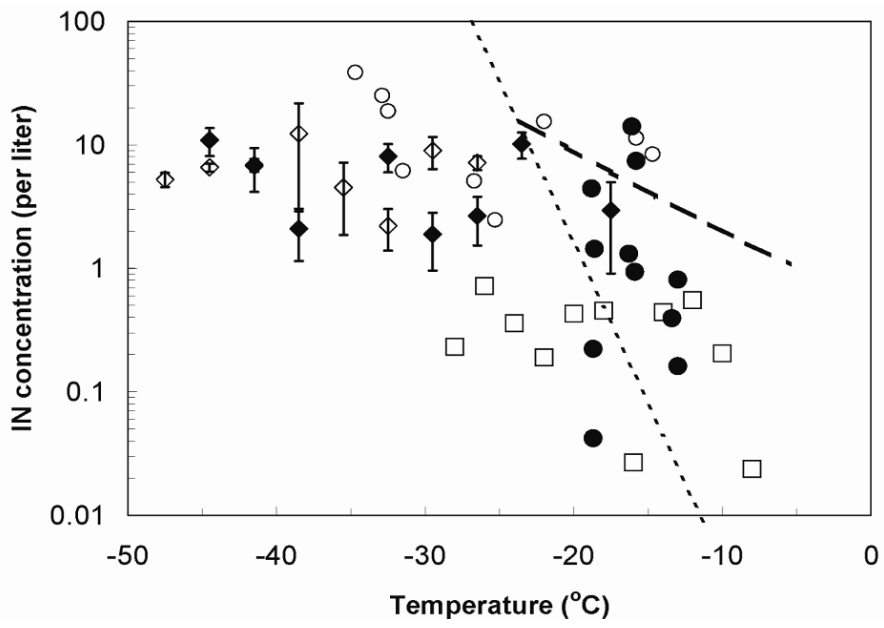

Fig. 4. Selected ice nuclei concentration data (per litre at standard temperature and pressure conditions) measured for sampling conditions exemplary of the free troposphere in selected studies since 1994. Continuous flow diffusion chamber (CFDC) data from the Colorado mountaintop measurements in Spring (Richardson et al., 2007, filled diamonds) and Fall (DeMott et al., 2003a, open diamonds) are 1 min average data binned at $4^{\circ} \mathrm{C}$, with $95 \%$ confidence intervals indicated by the error bars. Aircraft CFDC data from Fall season Arctic studies by Prenni et al. (2007) are binned in $2^{\circ} \mathrm{C}$ intervals (open squares). Also shown are CFDC data (filled circles) and controlled expansion cloud chamber data (open circles) processed from large bags collected in the vicinity of mountain wave clouds (Rogers and DeMott, 1995) in late Winter to early Spring. The dashed line shows the relation summarizing some of the first CFDC measurements made in the boundary layer (Meyers et al., 1992). The dotted line is based on Fletcher's summary of earlier ice nuclei measurements made at surface sites by a variety of techniques (Fletcher, 1962).

shows activity in comparable tests at temperatures $-5^{\circ} \mathrm{C}$ and lower.

The studies described in the preceding paragraph show a strong linkage between ice nuclei in soils and bacterial activity. Yet it is also known that ice nuclei in vegetation litters and in soils are not all bacterial cells. One such indication is that many of the ice nuclei in soils are smaller than the bacteria. The full extent of the relationship between ice nucleation active (INA) bacteria and ice nuclei in soils is not yet clear and there is much to be learned in future studies about the chemical, biological and physical characteristics of ice nuclei in soils.

The general abundance on plants of Pseudomonas syringae and other INA bacteria is well established (see review by Hirano and Upper, 2000), as is the role of these bacteria in frost damage to crops, and in the winter survival of insects (e.g., Lee et al., 1996; Lindow, 1983). It has also been shown that there are INA fungi (Kieft and Ruscetti, 1990; Pouleur et al., 1992), and INA pollen (Diehl et al., 2001), though much less is known about these than about the INA bacteria. Results from the period of intense research on these topics from the 1970s to the early 1990s are summarized in the book "Biological Ice Nucleation and Its Applications" by Lee et al. (1995). It is impossible to cover here the range of different aspects of what is known about INA bacteria, so just a few key points relevant to their potential atmospheric role will be summarized. Part of the laboratory work on the ice nucleation activity of bacteria and pollen is summarized in Sect. 8.
The ability to nucleate ice is known to exist in a handful of bacterial species and specific strains of those species. In any given population of INA bacteria, the fraction of cells that nucleate ice increases rapidly with decreasing temperature; the highest temperatures reported for a sample usually represent a fraction of less than about $10^{-4}$, but that fraction can rise several orders of magnitude within a few degrees. Cells do not have to be viable in order to exhibit nucleating ability, and even fragments of the bacteria can retain some of that ability (Phelps et al., 1986; Lee et al., 1995). Nucleating ability is due to the expression of a protein of about 150 to $180 \mathrm{kDa}$ in the outer cell membrane. Via laboratory experiments, the gene responsible for generating these proteins can be transferred to otherwise inactive species and change them to active ones, thereby demonstrating that this single gene is responsible for the INA properties. There is evidence that the aggregation of protein molecules in the cell membrane increases activity; for activity at $-3^{\circ} \mathrm{C}$ nucleation sites were found to be $10^{4} \mathrm{kDa}$ in size (Govindarajan and Lindow, 1988). The purified protein retains some activity but to a considerably reduced degree compared to activity in the cell. 


\section{Laboratory studies of ice nucleation by biological par- ticles}

The ice nucleation (IN) activity of bacterial cells was investigated in laboratory studies with different techniques. Early work by Maki et al. (1974) and Vali et al. (1976) found bacteria related to decaying leaves or decayed life litter, mainly Pseudomonas syringae species, to be IN active at temperatures as high as -2 to $-4^{\circ} \mathrm{C}$. However, it was found in the same work that there is only about 1 out of 10000 cells which is IN active at such high temperatures. The IN activity was related to the intact cells. Ultrasonic disruption shifted the INA of the same samples to lower temperatures between -8 and $-12^{\circ} \mathrm{C}$.

Yankofsky et al. (1981) investigated the ice nucleation activity of various cultured bacteria, so-called strains M1 and M4 from Israel, and the species Erwinia herbicola and Pseudomonas syringae originating from the United States. Droplets with a volume of $5 \mu \mathrm{l}$ and containing about $10^{6}$ cells of the INA bacteria showed strong activity at temperatures between -2 and $-10^{\circ} \mathrm{C}$, with M1 and M4 being active at somewhat warmer temperatures than the others, depending on the growth conditions. It was shown that INA decreased upon dilution of the bacterial suspensions or fragmentation of the intact cells by applying ultrasonic pulses of $20 \mathrm{~s}$ duration to the suspensions. Dilution by a factor of 100 shifted the INA curves of $\mathrm{M} 1$ by about $5^{\circ} \mathrm{C}$ to colder temperatures. This indicates that only a minor fraction of the cells is IN active at the warmest temperatures, in agreement with the earlier studies. Yankofsky et al. (1981) classified three groups of IN sites being active at temperatures of -2 to $-4^{\circ} \mathrm{C}$ (group I), -5 to $-7^{\circ} \mathrm{C}$ (group II), and -8 to $-10^{\circ} \mathrm{C}$ (group III). Group I appeared to be the least abundant (about 1 INA cell in $10^{4}$ ) in any cell population and required intact cells, whereas the most abundant group III (up to 1 in 300) was also observed in cell free fragments of bacterial suspensions with fragment sizes around $0.3 \mu \mathrm{m}$.

Levin and Yankofsky (1983) used the vertical wind tunnel of the University of California in Los Angeles (UCLA) to investigate bacteria-induced immersion and contact freezing of freely suspended water droplets with radii between 220 and $360 \mu \mathrm{m}$. A dry powder of freeze-dried bacteria (type M1, see Yankofsky et al., 1981), mechanically pulverized in a mortar, was directly suspended into the air flow of the wind tunnel for the contact nucleation experiments or used as suspension in water to inject the droplets for the immersion freezing experiments. Freezing of the droplets was observed at temperatures between -3 and $-9^{\circ} \mathrm{C}$, with the contact mode being somewhat more active than the immersion mode.

Ward and DeMott (1989) used the controlled-expansion cloud chamber of the Colorado State University (CSU) to investigate as a function of temperature and under simulated cloud forming conditions the ice nucleation activity of Snomax $^{T M}$, a product isolated and manufactured from Pseudomonas syringae cells for induction of ice nucleation in water sprayed from high pressure nozzles used by ski areas for "artificial" snowmaking. These studies used dispersions in air of pulverized powders of the freeze dried bacteria. The continuous change of ice nucleation activity during cloud parcel cooling was monitored and largely confirmed the behaviours identified by Levin and Yankofsky (1983), including increased nucleation rates within narrow temperature regimes.

The INA of Snomax was also investigated in a recent droplet fall tower experiment at the University of Washington (Wood et al., 2002). Droplets of about $33 \mu \mathrm{m}$ diameter taken from a $0.2 \mu \mathrm{m}$ filtrate of a suspension of 1 Snomax ${ }^{T M}$ pellet in $100 \mathrm{ml}$ water showed strong ice nucleation activity at temperatures below about $-8^{\circ} \mathrm{C}$. The filter retained intact cells which have sizes around $1 \mu \mathrm{m}$. That means the ice nucleation was induced by cell fragments, in reasonable agreement with previous studies also using fragmented cell samples. The smaller fragments showed INA only at lower temperature compared to the non-filtered Snomax ${ }^{T M}$ samples used by Ward and DeMott (1989).

Recently, the INA of some strains of Pseudomonas syringae and of Snomax ${ }^{T M}$ was investigated in the AIDA (Aerosol Interaction and Dynamics in the Atmosphere) facility of Forschungszentrum Karlsruhe. The advantage of the AIDA chamber is that, similar to the CSU cloud chamber, the experiments can be conducted at simulated cloud conditions and with the biological particles directly suspended in the aerosol phase. The AIDA chamber was used during the previous years for numerous heterogeneous ice nucleation studies with mainly soot and mineral dust aerosols (Möhler et al., 2005, 2006). Technical details and results of the AIDA experiments with bacteria will be the subject of an upcoming separate paper. Briefly, suspensions of cultured cells or Snomax ${ }^{T M}$ in water were directly sprayed into the large aerosol chamber at temperatures between -2 and $-10^{\circ} \mathrm{C}$. Resulting aerosol size distributions measured with a scanning mobility instrument and an aerodynamic particle spectrometer showed two distinct particle modes, a narrow, almost mono-disperse peak of intact cells with aerodynamic diameters of about $0.8 \mu \mathrm{m}$, and a poly-disperse mode of smaller particles with diameters between about 0.01 and $0.5 \mu \mathrm{m}$, probably composed of residual particles from evaporating droplets or containing cell fragments, at least in the case of Snomax ${ }^{T M}$ experiments. Almost none or very little INA was observed at temperatures warmer than $-8^{\circ} \mathrm{C}$. Even at temperatures below $-10^{\circ} \mathrm{C}$ only a minor fraction of the bacterial cells induced ice nucleation in the condensation or immersion freezing mode. The Snomax ${ }^{T M}$ aerosol showed, after $\mathrm{CCN}$ activation, increasing INA in the immersion freezing mode at temperatures below about $-8^{\circ} \mathrm{C}$, in agreement with the work by Wood et al. (2002) and the references cited therein. Further AIDA experiments are planned to measure more accurately the INA fraction of different bacterial strains and species as a function of temperature. Such data can be used together with new data about the abundance 
of the respective species in cloud droplets to more reliably evaluate and predict the role of bacteria in cloud processes.

Only a few laboratory studies so far have addressed the ice nucleation ability of pollen. The temperature dependent ice nucleation behaviour of various pollen species in the deposition, condensation, immersion, and contact mode was investigated using the vertical wind tunnel facility at the University of Mainz (Diehl et al., 2001, 2002; von Blohn et al., 2005). Grass, oak, birch, and pine pollen showed increasing ice activity in the condensation and immersion mode at temperatures between -8 and $-18^{\circ} \mathrm{C}$. Contact nucleation occurred already at somewhat warmer temperatures. The same pollen species showed no significant deposition nucleation at temperatures as low as $-32.5^{\circ} \mathrm{C}$ and ice supersaturation of up to 35\% (Diehl et al., 2001). In a second series of experiments in the wind tunnel, pollen from alder, Lombardy poplar, redtop grass, and Kentucky blue again showed increasing ice activity in the immersion mode at temperatures typically below -10 to $-16^{\circ} \mathrm{C}$ (von Blohn et al., 2005). The contact mode nucleation of these pollen types also started at somewhat warmer temperatures compared to the immersion mode. Alder pollen showed ice activity at the warmest temperatures. The concentration of pollen in the freezing droplets with diameters between 300 and $400 \mu \mathrm{m}$ and the number of collisions between pollen and droplets in the contact nucleation experiments were not quantified and the actual number fraction of pollen being ice-active in the various modes can unfortunately not be determined from these results. Thus, given the actual laboratory results, it is difficult to directly compare the ice nucleation efficiency of pollen to that of bacteria or other aerosols. However it may be noted that the tendency of contact nucleation to be active at warmer temperatures compared to immersion freezing was observed for both pollen and bacteria (Levin and Yankofsky, 1983).

How important biological aerosols are for ice initiation depends on the existence of effective mechanisms to deliver these larger particles to the levels of cold clouds and their concentrations. This does not necessarily mean that high ice nuclei concentrations are necessary to exert a strong impact on precipitation. The addition of large numbers of ice nuclei to convective clouds is sometimes associated with precipitation decreases (Teller and Levin, 2006), although feedbacks to cloud dynamics may modify other cloud properties of relevance to the global energy and water cycle (Phillips et al., 2005; van den Heever et al., 2006). These and other similar cloud modelling studies emphasize the fact that the action of $\mathrm{CCN}, \mathrm{GCCN}$ or IN on clouds and precipitation cannot be examined in isolation, but rather must consider their collective impacts.

\section{Cloud modelling studies}

In most cloud models the number of ice nuclei which are available to initiate the formation of primary ice particles in supercooled liquid clouds is calculated with simple equations mainly as function of the temperature and/or the ice supersaturation that serve as surrogates for explicitly resolving deposition and freezing mechanisms. These are sometimes supplemented with a formulation for contact-freezing nucleation. Such equations were, for example, deduced by Cotton et al. (1986) as a combination of earlier work partially based on measurements of atmospheric ice nuclei using a static filter approach (Fletcher, 1962; Huffman and Vali, 1973), by Meyers et al. (1992) using measurements of ice nuclei concentrations with novel continuous flow diffusion chambers (Al-Naimi and Saunders, 1985; Rogers, 1982) or by Cooper (1986) using measurements of ice particle number concentrations in the top layers of clouds where secondary ice nucleation processes had only a minor or negligible contribution to actual ice particle concentration. It is one of the major challenges of cloud physics to improve these equations and to formulate the formation of ice in cloud models also as a function of aerosol particles.

Although biological particles were found on mineral dust particles in the atmosphere and in cloud water samples, there is no clear evidence that they play a role in the formation of ice in clouds. Part of the problem may be related to the inability of the present IN measurement methods to identify biological particles as ice nuclei in cloud ice crystals and separating them from the inorganic substances. Furthermore, even if found inside ice crystals it is not yet clear what their importance is in the development of the clouds. This is partly because their concentrations may be too low, or that their effectiveness is expressed at temperatures not too relevant for the subsequent growth of the clouds. For example, it is possible that biological particles produce ice at temperatures only slightly below $0^{\circ} \mathrm{C}$. At that stage the difference in saturation between ice and water is too small to make the ice crystals grow rapidly. Nucleation of ice at slightly lower temperatures between -5 and $-10^{\circ} \mathrm{C}$ may dominate the ice growth, simply because the ice crystals at those temperatures may grow so much faster, that the head-start given to the crystals nucleated by the biological particles makes very little difference.

As discussed in Sect. 2, biological aerosol particles could act not only as IN but also as CCN and a major role of these aerosols could be to enhance the GCCN population. Even in concentrations as small as a few per liter, such particles have been shown in cloud modelling studies to enhance cloud growth and increase precipitation by accelerating the growth of rain drops. If the biological particles act as both GCCN and ice nuclei their effect could be very important. Another effect addressed in cloud modelling studies is secondary ice formation by the Hallett-Mossop mechanism (Hallett and Mossop, 1974) which involves the collision of ice particles with droplets larger than $25 \mu \mathrm{m}$ in diameter at temperatures between -4 and $-8^{\circ} \mathrm{C}$. The impact of biological particles on cloud development and initiation of precipitation could be very significant if they act as large or giant $\mathrm{CCN}$ and also as 
IN. The presence of such particles in an ascending air parcel of a convective cloud could form a few large droplets that would grow rapidly to sizes larger than $25 \mu \mathrm{m}$, before reaching the -4 to $-8^{\circ} \mathrm{C}$ temperature levels. At these levels the large droplets could play a role in the Hallett-Mossop mechanism by riming with existing ice crystals. Furthermore, being effective immersion IN, these biological particles can freeze the larger droplets.

Unfortunately, no measurements are available to substantiate this hypothesis. What is possible to do at this stage is to test the idea in numerical models in order to see the potential maximum effects of biological aerosol particles and to put the concept in perspective with respect to the effects of other possible competing processes. One such preliminary study was carried out by Levin et al. (1987). They used a time dependent one and a half dimensional model, which treats cloud microphysics in detail, but assumes a constant cloud radius and allows entrainment. Using data of biogenic ice nucleation from their laboratory study they inserted $1.2 \mu \mathrm{m}$ radius ice crystals at $-5^{\circ} \mathrm{C}$ in concentrations of $101^{-1}$ after $2000 \mathrm{~s}$ of cloud development. The total rain amount from the cloud was compared to the rain falling from an unseeded cloud. It was found that the seeded cloud precipitated considerably more than the control one, suggesting that the ice crystals grew by deposition and riming exceeding the respective growth of the ice in the unseeded cloud. A second set of simulation included seeding with such ice crystals at different temperatures from -5 to $-10^{\circ} \mathrm{C}$ as the cloud ascended. These simulations resulted in even larger amounts of rain on the ground. Although this study was preliminary and used a relatively simple model, it does indicate the potential effects of such particles. This approach should be continued by using more detailed models with two and three dimensions of single clouds and multiple clouds.

\section{Conclusions}

The abundance of biological sources of ice nuclei, and their activity at small supercoolings, makes them of potentially great importance to cloud processes. However, establishing the connection between the concentrations of biological particles and ice crytals in clouds has proven to be a rather difficult task. There is yet no direct evidence that bacterial ice nuclei participate in cloud processes to any significant degree. The greatest difficulty is the expected low concentration of INA bacteria in the air, coupled with the limitations of ice nucleus counters. The suggestion that INA fragments of bacteria in soils are more likely to be a source of atmospheric aerosol, either as separate entities or attached to mineral particles, is also difficult to evaluate due to the sampling and analytical requirements involved. On the other hand, the focus on ice nuclei of biological origin in regions of the earth with vegetation cover is reinforced by the fact that there are no other viable candidates known that could account for ice initiation in clouds at temperatures just a few degrees below $0^{\circ} \mathrm{C}$. In any event, it is clear that this possibility is subject to experimental confirmation, both by progress in the measurements of ice nuclei in the air and by analyses of ice nuclei in clouds and precipitation.

It was pointed out in related papers in this special issue that probably the most relevant effects of biological particles on microphysical processes in clouds are linked to their ability to act as normal and giant $\mathrm{CCN}$ and to initiate ice nucleation at relatively warm temperatures. Many studies have identified various species of INA bacteria at temperatures as warm as $-2^{\circ} \mathrm{C}$ and have investigated their IN efficiency as a function of temperature. However, there is still lack of information about the IN activity of bacteria directly isolated from cloud water and on changes of the IN efficiency due to chemical ageing like surface coating and other environmental impacts during the transport through the atmosphere. Furthermore, only very few data exist about the hygroscopic growth and CCN activity of biological particles and about the IN activity of pollen. Only a few modelling studies have investigated the sensitivity of cloud development and precipitation initiation to biological particles acting as CCN, GCCN, or IN.

In order to more accurately assess the impact of biological particles on cloud microphysics and thereby on precipitation as well as the regional and global climate we see a need of further work in the following directions:

- Laboratory experiments on the INA of relevant bacteria, pollen and other biological particles in terms of number fractions active in the different IN modes as a function of temperature.

- Examination of how ice nuclei found in many soils are related to biological activity in vegetative litter.

- Detailed studies of the ice nuclei in soils and litters to establish their physical and chemical characteristics and the dependence of ice nucleating ability on those characteristics.

- Measurements of the hygroscopic growth and CCN activity of pollen, bacteria, and other biological particles.

- Laboratory studies on the effect of chemical ageing, such as surface coating with e.g. organic compounds, on the hygroscopic growth, CCN behavior, and INA of bological aerosol particles.

- Development and application of new instruments for the direct measurement and identification of biological $\mathrm{CCN}$ and $\mathrm{IN}$ in the atmosphere, close to source areas as well as in and around clouds.

- Measurements of the number concentration, size, and nature of biological particles in the atmosphere. 
- More process and cloud modelling studies about the sensitivity of cloud development and precipitation rates on realistic $\mathrm{CCN}$ and IN behaviour of biological particles.

Acknowledgements. This work was initiated during a workshop on Microbiological Meteorology in Avignon, France, from 28 February to 4 March 2006. Thanks to C. Morris and D. Sands for the organisation of this Exploratory Workshop and to the European Science Foundation (ESF) for financial support. We thank D. Georgakopoulos, C. Morris, and T. Schwartz for selecting and preparing ice nucleation active bacterial cells for AIDA cloud chamber experiments.

Edited by: T. J. Battin

\section{References}

Al-Naimi, R. and Saunders, C. P. R.: Measurements of natural ice deposition and condensation-freezing ice nuclei with a continuous flow chamber, Atmos. Environ., 19, 1871-1882, 1985.

Anderson, B. J. and Hallett, J.: Supersaturation and time dependence of ice nucleation from the vapor on single crystal substrates, J. Atmos. Sci., 33, 822-832, 1976.

Barth, M., McFadden, J. P., Sun, J. L., Wiedinmyer, C., Chuang, P., Collins, B., Griffin, R., Hannigan, M., Karl, T., Kim, S. W., Lasher-Trapp, S., Levis, S., Litvak, M., Mahowald, N., Moore, K., Nandi, S., Nemitz, E., Nenes, A., Potosnak, M., Raymond, T. M., Smith, J., Still, C., and Stroud, C.: Coupling between land ecosystems and the atmospheric hydrologic cycle through biogenic aerosol pathways, B. Am. Meteorol. Soc., 86, 17381742, 2005.

Bauer, H., Giebl, H., Hitzenberger, R., Kasper-Giebl, A., Reischl, G., Zibuschka, F., and Puxbaum, H.: Airborne bacteria as cloud condensation nuclei, J. Geophys. Res., 108, 4658, doi:10.1029/2003JD003545, 2003.

Benz, S., Megahed, K., Möhler, O., Saathoff, H., Wagner, R., and Schurath, U.: T-dependent rate measurements of homogeneous ice nucleation in cloud droplets using a large atmospheric simulation chamber, J. Photoch. Photobio. A, 176, 208-217, 2005.

Bigg, E. K.: Measurement of concentrations of natural ice nuclei, Atmos. Res., 25, 397-408, 1990.

Cantrell, W. and Heymsfield, A.: Production of ice in tropospheric clouds - A review, B. Am. Meteorol. Soc., 86, 795-807, 2005.

Chen, Y. L., Kreidenweis, S. M., McInnes, L. M., Rogers, D. C., and DeMott, P. J.: Single particle analyses of ice nucleating aerosols in the upper troposphere and lower stratosphere, Geophys. Res. Lett., 25, 1391-1394, 1998.

Cooper, W. A.: Ice initiation in natural clouds., in: Precipitation Enhancement-A Scientific Challenge, edited by Braham, R., Meteor. Monogr. Amer. Meteor. Soc., 21, 29-32, 1986.

Cooper, W. A.: Ice formation in wave clouds: Observed enhancement during evaporation, in: Conf. Cloud Physics, Amer. Meteor. Soc., 147-152, Dallas, TX, 1995.

Cooper, W. A. and Vali, G.: The origin of ice in mountain cap clouds, J. Atmos. Sci., 38, 1244-1259, 1981.

Costa, A. A. and Sherwood, S.: Parcel model simulations of aerosol - warm phase cloud microphysics interactions over the Amazon,
Atmos. Chem. Phys. Discuss., 5, 481-508, 2005, http://www.atmos-chem-phys-discuss.net/5/481/2005/.

Cotton, R. J. and Field, P. R.: Ice nucleation characteristics of an isolated wave cloud, Q. J. Roy. Meteor. Soc., 128, 2417-2437, 2002.

Cotton, W. R., Tripoli, G. J., Rauber, R. M., and Mulvihill, E. A.: Numerical-Simulation of the Effects of Varying Ice Crystal Nucleation Rates and Aggregation Processes on Orographic Snowfall, J. Clim. Appl. Meteorol., 25, 1658-1680, 1986.

Cziczo, D. J., DeMott, P. J., Brock, C., Hudson, P. K., Jesse, B., Kreidenweis, S. M., Prenni, A. J., Schreiner, J., Thomson, D. S., and Murphy, D. M.: A method for single particle mass spectrometry of ice nuclei, Aerosol Sci. Tech., 37, 460-470, 2003.

Cziczo, D. J., DeMott, P. J., Brooks, S. D., Prenni, A. J., Thomson, D. S., Baumgardner, D., Wilson, J. C., Kreidenweis, S. M., and Murphy, D. M.: Observations of organic species and atmospheric ice formation, Geophys. Res. Lett., 31, L12116, doi:10.1029/2004GL019822, 2004.

Delene, D. J., Deshler, T., Wechsler, P., and Vali, G. A.: A balloonborne cloud condensation nuclei counter, J. Geophys. Res., 103, 8927-8934, 1998.

DeMott, P. J., Cziczo, D. J., Prenni, A. J., Murphy, D. M., Kreidenweis, S. M., Thomson, D. S., Borys, R., and Rogers, D. C.: Measurements of the concentration and composition of nuclei for cirrus formation, P. Natl. Acad. Sci. USA, 100, 14 655-14660, 2003a.

DeMott, P. J., Sassen, K., Poellot, M. R., Baumgardner, D., Rogers, D. C., Brooks, S. D., Prenni, A. J., and Kreidenweis, S. M.: African dust aerosols as atmospheric ice nuclei, Geophys. Res. Lett., 30, 1732, doi:10.1029/2003GL017410, 2003 b.

Diehl, K., Quick, C., Matthias-Maser, S., Mitra, S. K., and Jaenicke, R.: The ice nucleating ability of pollen - Part I: Laboratory studies in deposition and condensation freezing modes, Atmos. Res., 58, 75-87, 2001.

Diehl, K., Matthias-Maser, S., Jaenicke, R., and Mitra, S. K.: The ice nucleating ability of pollen: Part II. Laboratory studies in immersion and contact freezing modes, Atmos. Res., 61, 125133, 2002.

Duft, D. and Leisner, T.: Laboratory evidence for volumedominated nucleation of ice in supercooled water microdroplets, Atmos. Chem. Phys., 4, 1997-2000, 2004, http://www.atmos-chem-phys.net/4/1997/2004/.

Facchini, M. C., Mircea, M., Fuzzi, S., and Charlson, R. J.: Cloud albedo enhancement by surface-active organic solutes in growing droplets, Nature, 401, 257-259, 1999.

Feingold, G., Jiang, H. L., and Harrington, J. Y.: On smoke suppression of clouds in Amazonia, Geophys. Res. Lett., 32, L02804, doi:10.1029/2004GL021369, 2005.

Field, P. R., Hogan, R. J., Brown, P. R. A., Illingworth, A. J., Choularton, T. W., and Cotton, R. J.: Parametrization of iceparticle size distributions for mid-latitude stratiform cloud, Q. J. Roy. Meteor. Soc., 131, 1997-2017, 2005.

Fletcher, N. H.: Physics of rain clouds, Cambridge University Press, 1962.

Franc, G. D. and DeMott, P. J.: Cloud activation characteristics of airborne Erwinia carotovora cells, J. Appl. Meteorol., 37, 12931300, 1998.

Gagin, A. and Aroyo, M.: A thermal diffusion chamber for measurement of ice nuclei concentrations, J. Rech. Atmos., 4, 115- 
$122,1969$.

Govindarajan, A. G. and Lindow, S. E.: Size of Bacterial IceNucleation Sites Measured Insitu by Radiation Inactivation Analysis, P. Natl. Acad. Sci. USA, 85, 1334-1338, 1988.

Gultepe, I., Isaac, G. A., and Cober, S. G.: Ice crystal concentration versus temperature, Int. J. Climatol., 21, 1281-1302, 2001.

Hallett, J. and Mossop, S. C.: Production of secondary ice crystals during the riming process, Nature, 249, 26-28, 1974.

Heintzenberg, J., Okada, K., and Strom, J.: On the composition of non-volatile material in upper tropospheric aerosols and cirrus crystals, Atmos. Res., 41, 81-88, 1996.

Hirano, S. S. and Upper, C. D.: Bacteria in the leaf ecosystem with emphasis on Pseudomonas syringae - a pathogen, ice nucleus, and epiphyte, Microbiology and Molecular Biology Reviews, 64, 624-653, 2000.

Hobbs, P. V. and Rangno, A. L.: Ice Particle Concentrations in Clouds, J. Atmos. Sci., 42, 2523-2549, 1985.

Howell, W. E.: The growth of cloud drops in uniformly cooled air, J. Meteorol., 6, 134-149, 1949.

Huffman, P.: Supersaturation spectra of AgI and natural ice nuclei, J. Appl. Meteorol., 12, 1080-1082, 1973.

Huffman, P. J. and Vali, G.: The effect of vapor depletion on ice nucleus measurements with membrane filters, J. Appl. Meteor., 12, 1018-1024, 1973.

Isono, K., Komabayasi, M., and Ono, A.: The nature and origin of ice nuclei in the atmosphere, J. Meteorol. Soc. JPN, 37, 211-233, 1959.

Jaenicke, R.: Abundance of cellular material and proteins in the Atmosphere, Science, 308, p. 73, 2005.

Kanakidou, M., Seinfeld, J. H., Pandis, S. N., Barnes, I., Dentener, F. J., Facchini, M. C., Dingenen, R. V., Ervens, B., Nenes, A., Nielsen, C. J., Swietlicki, E., Putaud, J. P., Balkanski, Y., Fuzzi, S., Horth, J., Moortgat, G. K., Winterhalter, R., Myhre, C. E. L., Tsigaridis, K., Vignati, E., Stephanou, E. G., and Wilson, J.: Organic aerosol and global climate modelling: a review, Atmos. Chem. Phys., 5, 1053-1123, 2005, http://www.atmos-chem-phys.net/5/1053/2005/.

Kieft, T. L. and Ruscetti, T.: Characterization of Biological Ice Nuclei from a Lichen, J. Bacteriol., 172, 3519-3523, 1990.

Ko, G., First, M. W., and Burge, H. A.: Influence of relative humidity on particle size and UV sensitivity of Serratia marcescens and Mycobacterium bovis BCG aerosols, Tubercle Lung Dis., 80, 217-228, 2000.

Köhler, H.: The nucleus in the growth of hygroscopic droplets, T. Faraday Soc., 32, 1152-1161, 1936.

Koop, T.: Homogeneous ice nucleation in water and aqueous solutions, Z. Phys. Chem., 218, 1231-1258, 2004.

Korolev, A. V., Isaac, G. A., Cober, S. G., Strapp, J. W., and Hallett, J.: Microphysical characterization of mixed-phase clouds, Q. J. Roy. Meteor. Soc., 129, 39-65, 2003.

Lee, R. E., Warren, G. J., and Gusta, L. V.: Biological Ice Nuclation and Its Applications, APS Press; The American Phytopathological Society, St. Paul, Minnesota, 1995.

Lee, R. E., Costanzo, J. P., and Mugnano, J. A.: Regulation of supercooling and ice nucleation in insects, European Journal of Entomology, 93, 405-418, 1996.

Levin, Z. and Yankofsky, S. A.: Contact Versus Immersion Freezing of Freely Suspended Droplets by Bacterial Ice Nuclei, J. Appl. Meteorol., 22, 1964-1966, 1983.
Levin, Z., Yankofsky, S. A., Pardes, D., and Magal, N.: Possible Application of Bacterial Condensation Freezing to Artificial Rainfall Enhancement, J. Clim. Appl. Meteorol., 26, 1188-1197, 1987.

Lindow, S. E.: The role of bacterial ice nucleation in frost injury to plants, Annu. Rev. Phytopathol., 21, 363-384, 1983.

Maki, L. R., Galyan, E. L., Chang-Chien, M. M., and Caldwell, D. R.: Ice nucleation induced by Pseudomonas syringae, Applied and Environmental Microbiology, 28, 456-459, 1974.

Maria, S. F., Russell, L. M., Gilles, M. K., and Myneni, S. C. B.: Organic aerosol growth mechanisms and their climate-forcing implications, Science, 306, 1921-1924, 2004.

Mathias-Maser, S., ed.: Primary biological aerosol particles: their significance, sources, sampling methods and size distribution in the atmosphere, Atmospheric Particles, John Wiley and Sons, New Jersey, 1998.

Meyers, M. P., Demott, P. J., and Cotton, W. R.: New Primary Ice-Nucleation Parameterizations in an Explicit Cloud Model, J. Appl. Meteorol., 31, 708-721, 1992.

Möhler, O., Büttner, S., Linke, C., Schnaiter, M., Saathoff, H., Stetzer, O., Wagner, R., Krämer, M., Mangold, A., Ebert, V., and Schurath, U.: Effect of sulfuric acid coating on heterogeneous ice nucleation by soot aerosol particles, J. Geophys. Res., 110, D11210, doi:10.1029/2004JD005169, 2005.

Möhler, O., Field, P. R., Connolly, P., Benz, S., Saathoff, H., Schnaiter, M., Wagner, R., Cotton, R., Krämer, M., Mangold, A., and Heymsfield, A. J.: Efficiency of the deposition mode ice nucleation on mineral dust particles, Atmos. Chem. Phys., 6, 3007-3021, 2006, http://www.atmos-chem-phys.net/6/3007/2006/.

Morris, C. E., Georgakopoulos, D. G., and Sands, D. C.: Ice nucleation active bacteria and their potential role in precipitation, $\mathrm{J}$. Phys. IV, 121, 87-103, 2004.

Peccia, J., Werth, H. M., Miller, S., and Hernandez, M.: Effects of relative humidity on the ultraviolet induced inactivation of airborne bacteria, Aerosol Sci. Tech., 35, 728-740, 2001.

Petters, M. D. and Kreidenweis, S. M.: A single parameter representation of hygroscopic growth and cloud condensation nucleus activity, Atmos. Chem. Phys., 7, 19611971, 2007, http://www.atmos-chem-phys.net/7/1961/2007/.

Phelps, P., Giddings, T. H., Prochada, M., and Fall, R.: Release of cell-free ice nuclei by Erwinia herbicola, J. Bacteriol., 167, 496-502, 1986.

Phillips, V. T. J., Andronache, C., Sherwood, S. C., Bansemer, A., Conant, W. C., Demott, P. J., Flagan, R. C., Heymsfield, A., Jonsson, H., Poellot, M., Rissman, T. A., Seinfeld, J. H., Vanreken, T., Varutbangkul, V., and Wilson, J. C.: Anvil glaciation in a deep cumulus updraught over Florida simulated with the Explicit Microphysics Model. I: Impact of various nucleation processes, Q. J. Roy. Meteor. Soc., 131, 2019-2046, 2005.

Pouleur, S., Richard, C., Martin, J. G., and Antoun, H.: Ice nucleation activity in Fusarium acuminatum and Fusarium avenaceum, Appl. Environ. Microb., 58, 2960-2964, 1992.

Prenni, A. J., Harrington, J. Y., Tjernstrm, M., DeMott, P. J., Avramov, A., Long, C. N., Kreidenweis, S. M., Olsson, P. Q., and Verlinde, J.: Can ice-nucleating aerosols affect Arctic seasonal climate?, B. Am. Meteorol. Soc., 88, 541-550, 2007.

Pruppacher, H. R. and Klett, J. D.: Microphysics of clouds and precipitation, Kluwer Academic Publishers, Dordrecht, The Nether- 
lands, 1997.

Rasmussen, R. M., Geresdi, I., Thompson, G., Manning, K., and Karplus, E.: Freezing drizzle formation in stably stratified layer clouds: The role of radiative cooling of cloud droplets, cloud condensation nuclei, and ice initiation, J. Atmos. Sci., 59, 837860, 2002.

Richardson, M. S., DeMott, P. J., Kreidenweis, S. M., Cziczo, D. J., Dunlea, E., Jimenez, J. L., Thompson, D. S., Ashbaugh, L. L., Borys, R. D., Westphal, D. S., Cassucio, G. S., and Lersch, T. L.: Measurements of heterogeneous ice nuclei in the Western U.S. in springtime and their relation to aerosol characteristics, J. Geophys. Res., 112, D02209, doi:10.1029/2006JD007500, 2007.

Roberts, G. C. and Nenes, A.: A continuous-flow streamwise thermal-gradient $\mathrm{CCN}$ chamber for atmospheric measurements, Aerosol Sci. Tech., 39, 206-221, 2005.

Roberts, P. and Hallett, J.: A laboratory study of the ice nucleating properties of some mineral particulates, Q. J. Roy. Meteor. Soc., 94, 25-34, 1968.

Rogers, D. C.: Field and laboratory studies of ice nucleation in winter orographic clouds, Ph.D. thesis, University of Wyoming, 1982.

Rogers, D. C.: Measurements of natural ice nuclei with a continnuous flow diffusion chamber, Atmos. Res., 29, 209-228, 1993.

Rogers, D. C. and DeMott, P. J.: Measurements of natural ice nuclei, $\mathrm{CCN}$, and $\mathrm{CN}$ in winter clouds, in: AMS Conference on Cloud Physics, 139-144, Dallas, TX, 1995.

Rogers, D. C. and DeMott, P. J.: Ice crystal formation in wave clouds, airborne studies -10 to $-35^{\circ} \mathrm{C}$, in: American Meteorological Society Conference on Cloud Physics, Ogden, UT, 2002.

Rogers, D. C., DeMott, P. J., Kreidenweis, S. M., and Chen, Y. L.: A continuous-flow diffusion chamber for airborne measurements of ice nuclei, J. Atmos. Ocean Tech., 18, 725-741, 2001.

Rogers, R. R. and Yau, M. K.: A short course in cloud physics, Pergamon Press, Oxford, New York, 3rd edn., 1989.

Schaller, R. C. and Fukuta, N.: Ice nucleation by aerosol particles: experimental studies using a wedge-shaped ice thermal diffusion chamber, J. Atmos. Sci., 36, 1788-1802, 1979.

Schnell, R. C. and Vali, G.: Atmospheric ice nuclei from decomposing vegetation, Nature, 236, 163-165, doi:10.1038/236163a0, 1972.

Schnell, R. C. and Vali, G.: Biogenic Ice Nuclei: Part I. Terrestrial and Marine Sources, J. Atmos. Sci., 33, 1554-1564, doi:10.1175/1520-0469(1976)033, 1976.

Shilling, J. E., Fortin, T. J., and Tolbert, M. A.: Depositional ice nucleation on crystalline organic and inorganic solids, J. Geophys. Res., 111, D12204, doi:10.1029/2005JD006664, 2006.

Solomon, S., Qin, D., Manning, M., Alley, R. B., Berntsen, T., Bindoff, N. L., Chen, Z., Chidthaisong, A., Gregory, J. M., Hegerl, G. C., Heimann, M., Hewitson, B., Hoskins, B. J., Joos, F., Jouzel, J., Kattsov, V., Lohmann, U., Matsuno, T., Molina, M., Nicholls, N., Overpeck, J., Raga, G., Ramaswamy, V., Ren, J., Rusticucci, M., Somerville, R., Stocker, T. F., Whetton, P., Wood, R. A., and Wratt, D.: Contribution of Working Group I to the Fourth Assessment Report of the Intergovernmental Panel on Climate Change - Technical Summary, in: Climate Change 2007: The Physical Science Basis., edited by: Solomon, S., Qin, D., Manning, M., Chen, Z., Marquis, M., Averyt, K. B., Tignor, M., and Miller, H. L., Cambridge University Press, Cambridge, United Kingdom and New York, NY, USA, 2007.
Stein, D. and Georgii, H.-W.: Supersaturation spectra of ice nuclei at different locations in Europe and over the North Atlantic Ocean, J. Rech. Atmos., 19, 179-184, 1985.

Sun, J. M. and Ariya, P. A.: Atmospheric organic and bio-aerosols as cloud condensation nuclei $(\mathrm{CCN})$ : A review, Atmos. Environ. 40, 795-820, 2006.

Szyrmer, W. and Zawadzki, I.: Biogenic and anthropogenic sources of ice-forming nuclei: A review, B. Am. Meteorol. Soc., 78, 209228, 1997.

Tabazadeh, A., Djikaev, Y. S., and Reiss, H.: Surface crystallization of supercooled water in clouds, P. Natl. Acad. Sci. USA, 99, $15873-15878,2002$.

Targino, A. C., Krejci, R., Noone, K. J., and Glantz, P.: Single particle analysis of ice crystal residuals observed in orographic wave clouds over Scandinavia during INTACC experiment, Atmos. Chem. Phys., 6, 1977-1990, 2006, http://www.atmos-chem-phys.net/6/1977/2006/.

Teller, A. and Levin, Z.: The effects of aerosols on precipitation and dimensions of subtropical clouds: a sensitivity study using a numerical cloud model, Atmos. Chem. Phys., 6, 67-80, 2006, http://www.atmos-chem-phys.net/6/67/2006/.

Vali, G.: Ice nucleation relevant to hail formation, Stormy Weather Group Scientific Report, MW-58, 62 pp., 1968.

Vali, G.: Nucleation Terminology, B. Am. Meteorol. Soc., 66, 1426-1427, 1985a.

Vali, G.: Atmospheric ice nucleation - a review, J. Rech. Atmos., 19, 105-115, 1985b.

Vali, G., Christensen, M., Fresh, R. W., Galyan, L. R., Maki, L. R., and Schnell, R. C.: Biogenic Ice Nuclei. Part II: Bacterial Sources, J. Atmos. Sci., 33, 1565-1570 , doi:10.1175/15200469(1976)033, 1976.

van den Heever, S. C., Carrio, G. G., Cotton, W. R., DeMott, P. J., and Prenni, A. J.: Impacts of nucleating aerosol on Florida storms. Part I: Mesoscale simulations, J. Atmos. Sci., 63, 1752 1775, 2006.

von Blohn, N., Mitra, S. K., Diehl, K., and Borrmann, S.: The ice nucleating ability of pollen: Part III: New laboratory studies in immersion and contact freezing modes including more pollen types, Atmos. Res., 78, 182-189, 2005.

Wallace, J. M. and Hobbs, P. V.: Atmospheric Science: An Introductory Survey, Academic Press, 2nd edn., 2006.

Ward, P. J. and DeMott, P. J.: Preliminary experimental evaluation of Snomax, Pseudomonas syringae, as an artificial ice nucleus for wheather modification, J. Wea. Mod., 21, 9-13, 1989.

Wood, S. E., Baker, M. B., and Swanson, B. D.: Instrument for studies of homogeneous and heterogeneous ice nucleation in freefalling supercooled water droplets, Rev. Sci. Instrum., 73, 39883996, 2002.

Yankofsky, S. A., Levin, Z., Bertold, T., and Sandlerman, N.: Some basic characteristics of bacterial freezing nuclei, J. Appl. Meteorol., 20, 1013-1019, 1981.

Yin, Y., Levin, Z., Reisin, T. G., and Tzivion, S.: The effects of giant cloud condensation nuclei on the development of precipitation in convective clouds - a numerical study, Atmos. Res., 53, 91-116, 2000.

Young, K. C.: Microphysical processes in clouds, Oxford University Press, New York, 1993. 